\title{
Status Analysis of Development and Cultivation of Chinese Undergraduate Party Members
}

\author{
Wei ZHAO ${ }^{1}$, Long-fei $\mathrm{LV}^{1}{ }^{,}$, Jun-ming $\mathrm{KANG}^{1}$, Ji-ming $\mathrm{HU}^{1}$ and Qing \\ WANG $^{1}$ \\ ${ }^{1}$ School of Electrical Engineering, Wuhan University, Wuhan, Hubei, China \\ 3078210774@qq.com
}

\begin{abstract}
Keywords: Undergraduate party member, Party member development, Party building work.
\end{abstract}

\begin{abstract}
Development and cultivation of undergraduate party members concern the general situation of socialist construction with Chinese characteristics, and great party construction project. Through the analysis of the advantages and disadvantages of college student party members development in our country, putting forward the corresponding improvement, in order to enhance the effectiveness of development and cultivate the university student party members.
\end{abstract}

\section{Development and Cultivation Status of Chinese Undergraduate Party Members}

\section{Advantages Development and Cultivation Mode of Chinese Undergraduate Party} Members

Active Implementation of Ideological and Political Education for Party Members. In the new period of reform and opening up, Chinese Communist Party proposed a series of new views and new measures to enhance ideological and political education. These lay theoretical foundation for quality assurance of undergraduate party members and for development of undergraduate party members. Meanwhile, they make development of undergraduate party members thrive. Ideological education work is beneficial for undergraduate party members to establish communist lofty ideals inwardly and offers powerful spiritual strength for quality assurance mechanism of undergraduate party members. In 1990, the Central Committee of the Communist Party of China issued Notice on Enhancing Party Building in Institutions of Higher Education. Since then, annual nationwide university party building conference has been held as scheduled to discuss current situation and prospect of university student party building, in the hope of keeping improving the quality of undergraduate party members.

Effective Construction of Party Member Quality Assurance Mechanism. Quality assurance mechanism construction for undergraduate party members has achieved significant progress. "It is necessary to carry out ideological and political education for undergraduates, well develop undergraduate party members and gather excellent undergraduates in party member team". This is the guiding ideology of development of undergraduate party members. The quality of undergraduate party members decides the success or failure of socialist construction. In order to guarantee the quality of undergraduate party members, Chinese Communist Party continuously formulates measures and issues documents. Chinese Communist Party hopes to guarantee the quality of undergraduate party members through system construction. As undergraduate party building work goes deep, the researches on quality assurance mechanism of undergraduate party members increase gradually. Aiming at the 
problems existing in development of undergraduate party members, university party building workers keep on studying and exploring quality assurance mechanism and have obtained preliminary achievements.

\section{Shortcomings of Development and Cultivation Mode of Chinese Undergraduate Party Members}

Working Procedure Lacks Norms. During development of undergraduate party members, some party workers often fail to work according to rules and regulations in order to save time, fail to arrange trainers for activists of party membership application and fail to cultivate and fill in training investigation registration sheet one year in advance as required. Instead, they let the activists of party membership application self-develop, self-cultivate and self-grow. Only when they consider the activists of party membership application basically comply with the conditions of a probationary party member will they hurry to supplement relevant teaching materials, and arrange training time. In short, they cannot carefully execute relevant policy regulations. Since working system and working procedure lack norms, many potential applicants are lost in this process, or probationary party members who scrape in party member team fail to reach the due effect, because they are not well trained.

Some student party members fail to fully cultivate party spirit. In recent years, the vast majority of undergraduate party members can consciously maintain the image of the party, stick to and publicize path and policy of the party, actively boycott impacts of various bad phenomena and consciousness and show brisk vitality and vigor. However, some student party members fail to fully cultivate party spirit, pay no attention to maintaining the image of the party, relax and even give up political study after joining the party, and weaken party member awareness and the concept of party spirit. Meanwhile, their goal pursuit weakens, and they lose their enterprise and sense of responsibility.

\section{Suggestions on Improving Development and Cultivation of Chinese Undergraduate Party members}

Cultivation of undergraduate party members is based on certain political goal and aims to reach the purpose of party spirit culture and political accomplishment under effective system guarantee through selection, recommendation, party school training, brand training. In such way, they can own the awareness of serving the people wholeheartedly and firm communistic belief. Thus, scientific guarantee mechanism should be established to ensure cultivation quality of student party members.

\section{To Perfect Party Member Selection Mechanism and Grasp the Quality of "entry"}

Selection and recommendation are the preconditions of cultivation quality of student party members, and also the key to "selecting good seeds". Party workers must control the "entry" for party member development, and adhere to comprehensive quality in political accomplishment, organizational discipline, learning ability and mass base as assessment criterion. In terms of development procedure, the procedure of each link should be controlled strictly, including recommendation, cultivation and education of activists of party membership application; political review and publicity of development objects; acceptance, education, investigation, publicity and regularization of probationary party members. The principle of "developing the party member whenever he (she) becomes mature" should be adhered to. In the aspect of development 
discipline, accountability system for party member development should be established. For the organizations and individuals violating development procedure and neglecting the duties of investigation, their liability should be investigated, and they should be given criticism and education or disciplinary sanction.

\section{To Optimize Party School Training System and Boost Actual Effect of Cultivation and Education}

Party school training is an important link and means to improve the quality of party members. Through party school training, activists of party membership application will form relatively complete theoretical knowledge system of the party, and boost political accomplishment and party spirit culture. It is necessary to optimize evaluation and employment system of party school teachers. Evaluation of teachers should be centered by teaching guidance ability, combine quantitative evaluation and qualitative evaluation. In addition, it is required to specify the rights and obligations of party school teachers and give teachers more autonomous right in classroom teaching, lecture and practice guidance so as to motivate their enthusiasm and creativity. Party school training form should avoid single classroom teaching mode, and the mode of emotional experience and practical training should be adopted to make training objects further firm ideal and faith and correct the motivation of party joining. The mode of emotional experience and practical training includes organizing visit and investigation, paying a visit to scenic spots of revolutionary significance and participating in community service etc. In terms of party school setting, it is based on university-level party school and assisted by college (department) branch party school to carry out hierarchical party school education and practically improve training effect.

\section{To Make Quantitative Evaluation Standard Strict and Enhance Quality Culture Construction}

Quantitative evaluation aims to assess ideology, politics, study, work, life and social practice of activists of party membership application. It plays a great role in improving ideological and political quality of undergraduates, purifying the motivation of joining the party and confirming development direction. It is required to scientifically set and select all kinds of quantitative evaluation indexes, establish fair, just, rational and feasible quantitative evaluation index system, effectively combine objective management and process management, establish educational training system for undergraduate activists, talk system for party joining cultivation and investigation, regularization assessment system for probationary party members, school discipline violation punishment system and objective management system for student party members, continuously motivate cultivation and management service potential of party organizations at each level. Besides, quality culture construction should be enhanced, and training atmosphere should be optimized. Party organizations at each level should improve cognition of quality culture connotation, deem quality as the core task and ultimate objective of student party member cultivation, create democratic and harmonious student party member cultivation atmosphere and promote healthy growth of party members.

\section{Summary}

To well develop contemporary undergraduate party members is an important move to enhance party building under new situation and also an important content of cultivating 
socialism constructers and successors. Meanwhile, it is a necessary method to promote science level of university party building. At present, although some achievements have been gained in development of undergraduate party members, many problems still exist. Only continuously explore learning can improve the effectiveness of college student party members development in our country.

\section{References}

[1] Chen Yingjun, Construction of quality guarantee system for undergraduate party member development [J]. Heilongjiang Researches on Higher Education, 2007, 04:74-76.

[2] Zhu Qinwen, Huang Xiaoheng, Tao Jidong, Chen Hanying, Liu Zhiguo, Study on problems and countermeasures in development of contemporary undergraduate party member [J]. School Party Building and Ideological Education, 2010, 31:26-28.

[3] Shi Shaowei, Zhang Qingwen, Problems and countermeasures of development of undergraduate party members [J]. Journal of University Counselors, 2009, 01:59-62.

[4] Zhang Shangzi, Strengthening and improving development of undergraduate party members in exploration and innovation [J]. Journal of Henan Polytechnic University (Social Sciences), 2005, 02:105-107+110. 